\title{
CONTAMINANT DISTRIBUTIONS AT TYPICAL U.S. URANIUM MILLING FACILITIES AND THEIR EFFECT ON REMEDIAL ACTION DECISIONS
}

\author{
Steve Hamp \\ U.S. Department of Energy \\ UMTRA Project Office \\ Albuquerque Operations Office \\ Albuquerque, New Mexico \\ Timothy J. Jackson \\ Geraghty and Miller, Inc. \\ Albuquerque, New Mexico \\ Patrick W. Dotson \\ Roy F. Weston, Inc. \\ Albuquerque, New Mexico
}

\section{INTRODUCTION}

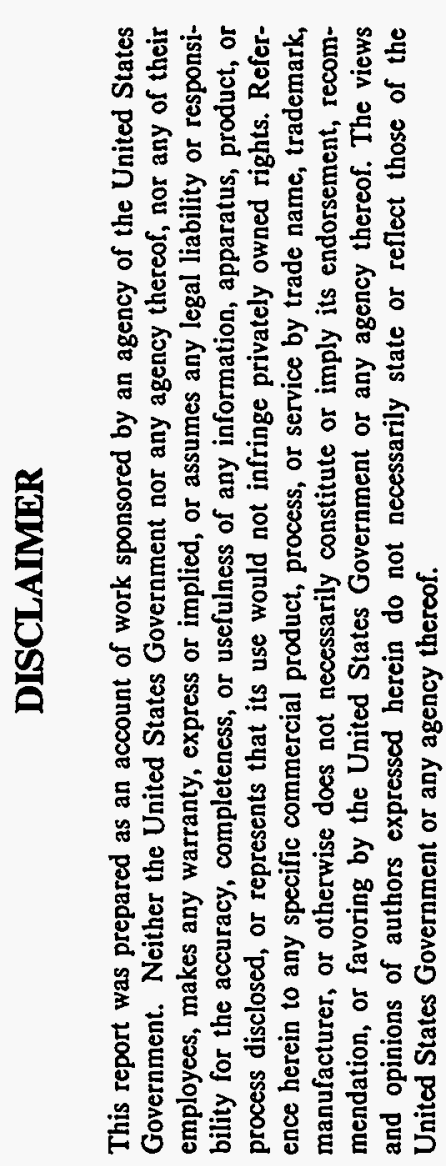

Past operations at uranium processing sites throughout the United States have resulted in local contamination of soils and ground water by radionuclides, toxic metals, or both. Understanding the origin of contamination and how the constituents are distributed is a basic element for planning remedial action decisions. This paper describes the radiological and nonradiological species found in ground water at a typical U.S. uranium milling facility. The paper will provide the audience with an understanding of the vast spectrum of contaminants that must be controlled in planning solutions to the long-term management of these waste materials.

\section{URANIUM MILL TAILINGS REMEDIAL ACTION OVERVIEW}

In the period between the Manhattan Project (early 1940s) and the 1960s, uranium mining and milling in the United States expanded rapidly. While initial expansion was spurred by the defense needs of the Cold War, development of nuclear power plants in the 1950s fueled further expansion. Production peaked in the early 1960s at a little over 15,000 metric tons a year of concentrated uranium. Concentrated uranium is obtained from uranium ore through a combination of crushing, grinding, 


\section{DISCLAIMER}

Portions of this document may be illegible in electronic image products. Images are produced from the best available original document. 
and extraction. During the milling process, other uranium decay products, such as thorium-230 and radium-226, remain in the waste material and account for 85 percent of the ore's original radioactivity. This waste material, commonly referred to as tailings, was left behind in large piles when the mills shut down. Little or no effort was made to provide for the long-term disposal or stabilization of the tailings when many of the mills were abandoned.

In the late 1960 s, direct gamma radiation and radon gas and its decay products at the abandoned mill sites were determined to be potential health hazards. As the concern about possible cancer links to radon grew, the U.S. Congress passed the Uranium Mill Tailings Radiation Control Act (UMTRCA) in 1978 to authorize the U.S. Department of Energy (DOE) to remediate and to permanently dispose of the radioactive mill tailings at 24 abandoned mill sites and associated vicinity properties (VP). The mill sites are located in 10 states: Arizona, Colorado, Idaho, New Mexico, North Dakota, Oregon, Pennsylvania, Texas, Utah, and Wyoming (Figure 1). By an amendment to the UMTRCA in 1983, the DOE was also given responsibility for cleaning up VPs near Edgemont, South Dakota.

To comply with the law, the DOE established the Uranium Mill Tailings Remedial Action (UMTRA) Project Office at the Albuquerque Operations Office in Albuquerque, New Mexico. Since 1983, the UMTRA Project Office has been performing remedial action on surface contamination, which includes uranium mill tailings and abandoned mill buildings. This effort, called the UMTRA Surface Project, is responsible for controlling the exposure and dispersion of uranium mill tailings by stabilizing this material in disposal cells.

Previous uranium processing activities resulted in the formation of contaminated ground water beneath and, in some cases, downgradient of most of the 24 inactive mill sites designated for remediation under UMTRCA (Figure 2). This contaminated ground water often contains elevated levels of hazardous constituents. The UMTRA Ground Water Project was initiated to evaluate the extent of this contamination and take whatever remedial action necessary to protect human health and the environment by meeting U.S. Environmental Protection Agency (EPA) standards.

The law authorizing DOE to clean up the inactive uranium mill tailings sites also directed the EPA to establish standards to be used during remedial action. The U.S. Nuclear Regulatory Commission (NRC) was directed to provide consultation and concurrence in the type of remedial action that would be performed. Before remedial action is started, the DOE must comply with the National Environmental Policy Act and perform detailed studies of the environmental impacts at each site. 


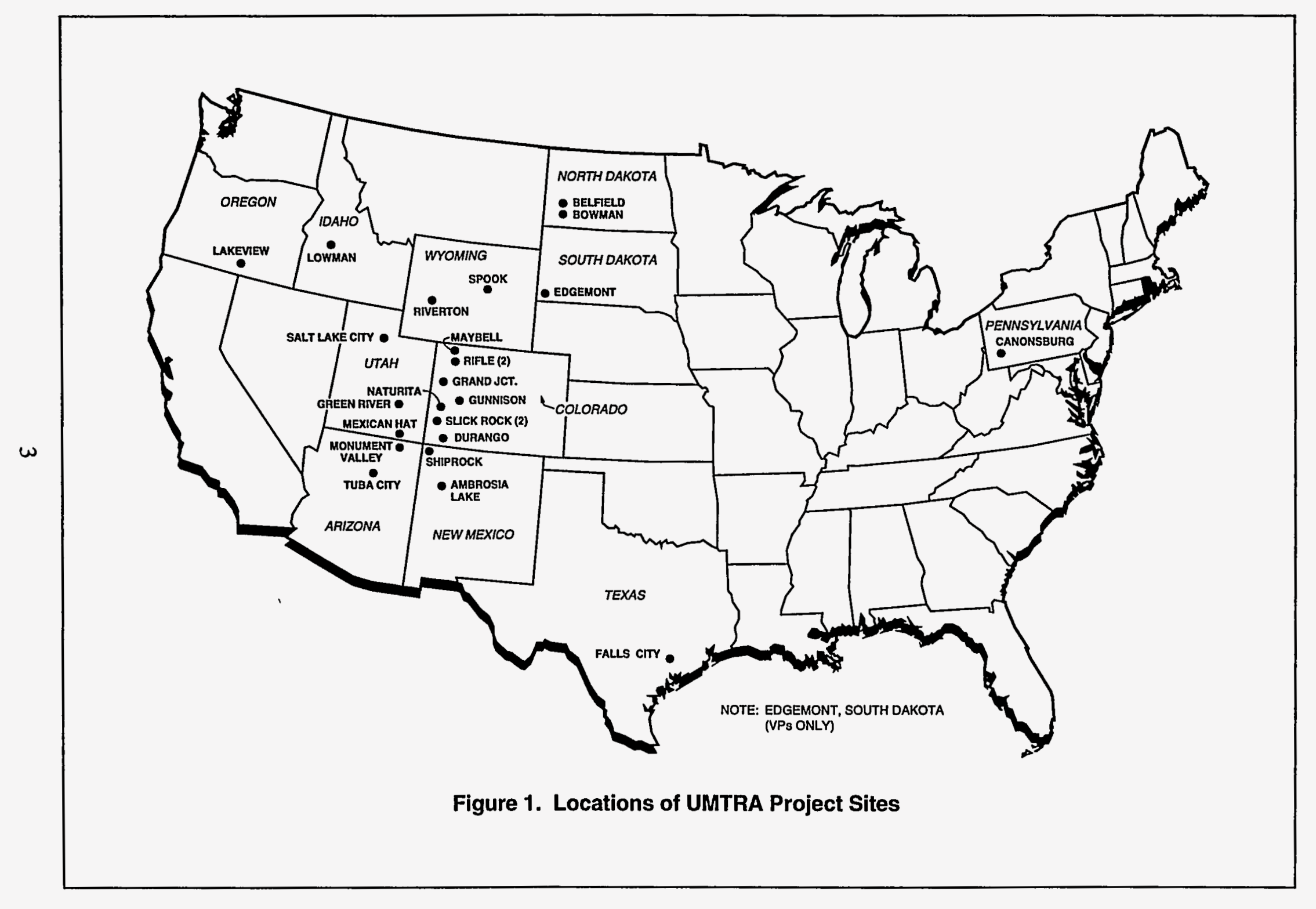




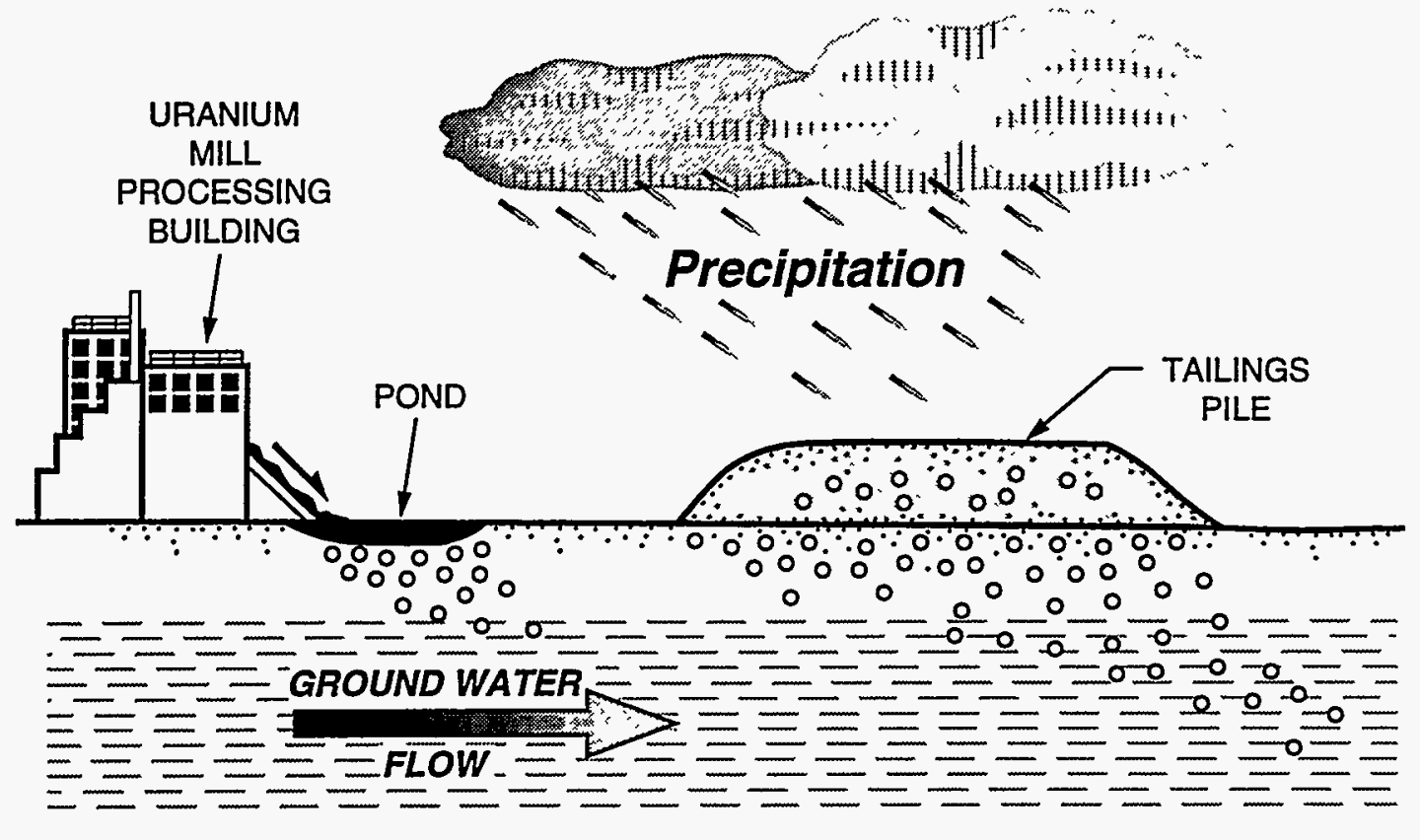

LEGEND

EE三 GROUND WATER

${ }^{\circ} \mathrm{OO}_{\mathrm{O}}$ CONTAMINANTS

Figure 2. Uranium Mill Processing Site 


\section{MILLING PROCESSES AND PROCESS REAGENTS USED AT UMTRA PROJECT SITES}

The 24 designated UMTRA Project processing sites were active for varying lengths of time from the 1940s into the 1970s. The available historical record of milling processes, quantities of chemicals used, and waste volume produced by previous operations at current UMTRA Project sites is incomplete. Ore types processed at the sites were typically vanadate sandstone deposits. The two sites in North Dakota processed uraniferous lignite ores. The Lakeview, Oregon, site processed arsenate ores predominantly. Information on the milling processes used was obtained from publications covering uranium milling at the time of plant operation. Information on milling processes and ore types used at the sites is summarized in Table 1.

The milling process used at each site depended on the type of ore being milled. The process frequently changed throughout the plant's history as one ore source was depleted and additional ore sources were discovered. The uranium extraction process was accomplished by either the acid or alkaline leach method. Commonly used reagents were sulfuric acid for the former technique and sodium carbonate for the latter. Acid leaching was the most effective technique and was used at most sites during their history. Alkaline leaching was used for ores with a high lime content and was used at the Ambrosia Lake, New Mexico; Durango, Colorado; Naturita, Colorado; Riverton, Wyoming; and Tuba City, Arizona, sites (Figure 1) during all or part of their history.

Solvent extraction and resin ion exchange were the two major techniques used for concentration and purification of the leach solutions. Solvent extraction involved the transfer of the dissolved uranium from the aqueous phase into an organic phase. Solvent extraction generally involved the use of alkyl phosphoric compounds or quaternary amines and long chain alcohols in an inert carrier such as kerosene or fuel oil. Typically, over 90 percent of the solvent consisted of this inert carrier (Merritt 1971). A second process was used to recover or strip the purified and concentrated uranium product into a second aqueous phase from which the uranium could be precipitated. Typical stripping agents included nitrates, chlorides, sulfates, carbonates, hydroxides, and acids. Solvent extraction was the primary concentration technique used at UMTRA Project sites.

Resin ion exchange used strong and intermediate base anionic (typically ammoniumbearing) synthetic resins. The acid or alkaline leach solutions were passed through these media, which selectively adsorbed the uranium. An eluting reagent was then used to release the uranium from the resins to produce a purified and concentrated uranium solution. Typical eluting agents included nitrate, chloride, and sulfuric acid solutions. Uranium could then be precipitated directly from this solution. Resin ion 
Table 1. Ore Type and Milling Processes Used at UMTRA Project Sites

\begin{tabular}{|c|c|c|}
\hline UMTRA Project Site & Ore Type & Milling Process \\
\hline Ambrosia Lake, New Mexico & Limestones & Alkaline leach \\
\hline Belfield, North Dakota & Lignites & Rotary kiln lignite ore-burning \\
\hline Bowman, North Dakota & Lignites & Lignite ore-burning \\
\hline Canonsburg, Pennsylvania & $\begin{array}{l}\text { Vanadates and other ores, } \\
\text { concentrates, and residues }\end{array}$ & N/A \\
\hline Durango, Colorado & N/A & $\begin{array}{l}\text { Acid leach, alkaline leach, and } \\
\text { solvent extraction }\end{array}$ \\
\hline Falls City, Texas & Sandstones & Acid leach and solvent extraction \\
\hline Grand Junction, Colorado & Vanadates and oxides & Acid leach and solvent extraction \\
\hline Green River, Utah & Vanadates & Upgrader unit and acid leach \\
\hline Gunnison, Colorado & Oxides, silicates, and phosphates & Acid leach and solvent extraction \\
\hline Lakeview, Oregon & Arsenate and phosphates & Acid leach and solvent extraction \\
\hline Lowman, Idaho & Monazites & N/A \\
\hline Maybell, Colorado & N/A & $\begin{array}{l}\text { Upgrader unit, acid leach, and ion } \\
\text { exchange }\end{array}$ \\
\hline Mexican Hat, Utah & Sulfides & Acid leach and solvent extraction \\
\hline Monument Valley, Arizona & Vanadates & Upgrader unit and acid leach \\
\hline Naturita, Colorado & Vanadates & Alkaline leach and acid leach \\
\hline New Rifle, Colorado & Vanadates & Acid leach and solvent extraction \\
\hline Old Rifle, Colorado & $\begin{array}{l}\text { Vanadates and lignite ash from } \\
\text { the Belfield site }\end{array}$ & Water leach and acid leach \\
\hline Riverton, Wyoming & N/A & $\begin{array}{l}\text { Acid leach, solvent extraction, and } \\
\text { Alkaline leach }\end{array}$ \\
\hline Salt Lake City, Utah & N/A & Acid leach and solvent extraction \\
\hline Shiprock, New Mexico & Vanadates & $\begin{array}{l}\text { Acid leach, solvent extraction, and } \\
\text { ion exchange }\end{array}$ \\
\hline Slick Rock, Colorado ${ }^{a}$ & Vanadates & Acid leach \\
\hline Spook, Wyoming & Vanadates & Acid leach and ion exchange \\
\hline Tuba City, Arizona & N/A & $\begin{array}{l}\text { Acid leach, ion exchange, and } \\
\text { alkaline leach }\end{array}$ \\
\hline \multicolumn{3}{|c|}{$\begin{array}{l}\text { The Slick Rock, Colorado, UMTRA Project site actually consists of two separate sites. They bave been } \\
\text { combined for this table. } \\
\text { N/A - not available. }\end{array}$} \\
\hline
\end{tabular}


exchange was used at the Maybell, Colorado; Shiprock, New Mexico; Spook, Wyoming; and Tuba City, Arizona, sites (Figure 1) during part of their history.

Precipitation of uranium from acid leach solutions to produce the final uranium product, yellowcake, was accomplished by two principal methods: direct neutralization with a base, such as lime, caustic soda, magnesia, or ammonia, and direct precipitation from acid solution with hydrogen peroxide. Precipitation of uranium from alkaline leach solutions was accomplished by one of the following methods: the addition of a strong base, acidification followed by neutralization with a base, or hydrogen reduction.

From the above discussion of milling processes used, it is obvious that a wide range of chemical wastes could be expected at UMTRA Project sites. The list of chemicals includes sulfuric acid, sulfates, carbonates, chlorides, nitrates, ammonia, lime, magnesium, manganese, and organic compounds, such as alkylphosphates, amines, alcohols, kerosene, and fuel oil. In addition, elements associated with uranium ores, such as uranium, selenium, vanadium, molybdenum, and arsenic may be dissolved in the waste stream. Approximately 0.91 to 4.55 tonnes of process waste water must be disposed of for every tonne of ore processed (Merritt 1971). Many of the milling sites processed between 273 to 910 tonnes of ore per day. Uranium milling required large amounts of water, ranging from 834 to 4172 liters of water per tonne of ore processed (Merritt 1971). A typical site processing 455 tonnes of ore per day required 2087 liters of water per tonne of ore processed; approximately 347 million liters ( 280 acre-feet) of water would be required at that site per year. Most of this water would end up as process waste water (raffinate) that, in most cases, would seep into the ground. This ground water pollution is a critical problem for UMTRA Project remediation.

\section{TAILINGS SOLUTION CHEMISTRY}

Generally, raffinate was the source of the solutions in the tailings because the tailings and raffinate were commonly slurried together to the tailings piles (though in some instances, excess raffinate was disposed of through evaporation ponds). Little is known about the specific types and amounts of process chemicals used at each site, and even less information is available for the composition of the raffinates. One analysis using available sources (Table 2 ) indicates that these solutions were generally acidic, with a $\mathrm{pH}$ of about 1 , with total dissolved solids exceeding 120,000 milligrams per liter, and with large amounts of dissolved metals.

Because there are few records available for the composition of waste solutions produced at the UMTRA Project sites, tailings solutions have been collected (using suction lysimeters) to characterize the source of ground water contamination. The 
Table 2. Analysis of Raffinate Produced at the Durango, Colorado, Mill Site ${ }^{a}$

\begin{tabular}{|c|c|}
\hline Parameter & Raffinate Concentration ${ }^{b}$ \\
\hline $\begin{array}{l}\text { Arsenic } \\
\text { Beryllium } \\
\text { Chloride } \\
\text { Copper } \\
\text { Fluoride } \\
\text { Iron } \\
\text { Manganese } \\
\text { pH } \\
\text { Ra-226 (picocuries per liter) } \\
\text { Selenium } \\
\text { Sodium } \\
\text { Sulfate } \\
\text { Total dissolved solids } \\
\text { Uranium } \\
\text { Vanadium } \\
\text { Zinc }\end{array}$ & $\begin{array}{c}16 \\
30 \\
6500 \\
23 \\
12 \\
370 \\
200 \\
0.8 \\
148 \\
<0.01 \\
16,000 \\
66,000 \\
120,000 \\
4^{\mathrm{c}} \\
250 \\
300^{\mathrm{c}}\end{array}$ \\
\hline \multicolumn{2}{|c|}{ 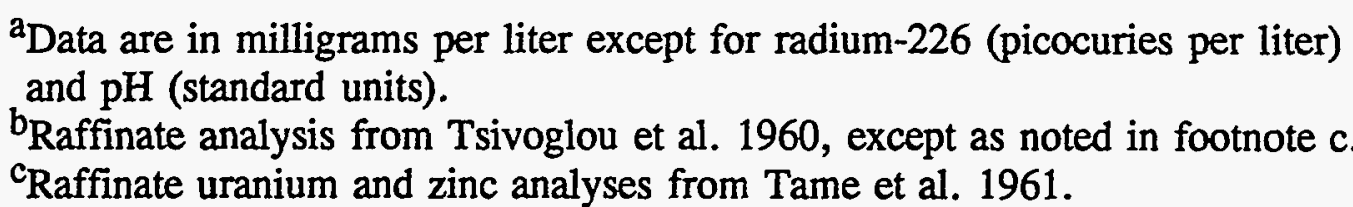 } \\
\hline
\end{tabular}


results of analyses of tailings solutions collected are summarized in Table 3. In this table, constituents are listed in decreasing order of concentration within three broad categories: constituents having maximum concentration limits (MCL) for ground waters as defined by the EPA standards, other metals and metalloids, and other nonmetals.

Analysis to detect all major elements and hazardous inorganic constituents (Table 3) confirms their presence in these tailings fluids. The sources of several constituents are reagents used to process ores, including sulfate, ammonium, nitrate, chloride, and sodium. Other constituents are derived from dissolution of the ore-bearing rocks during the uranium extraction (acid or alkaline leach) stage of processing. In general, concentrations and frequency of occurrence of these constituents simply reflect the normal abundance (Krauskopf 1967) of such elements in common rocks. Thus, calcium, magnesium, potassium, aluminum, iron, manganese, nickel, and zinc, which are abundant in rocks, occur at high concentrations in the tailings solutions. By contrast, elements that occur at low levels in normal rocks, such as antimony, silver and mercury, occur less frequently and at low levels in tailings solutions.

Superimposed on the general trend of occurrence by normal abundance are elements concentrated in the sandstone-type uranium ores. These include uranium, molybdenum, selenium, vanadium, arsenic, and, to a lesser extent, cadmium and chromium. As a result of mineralization, these occur in the tailings solutions at levels greater than expected in average rocks. However, lead (an element associated with some uranium deposits) occurs at levels notably less than expected.

The tailings solutions are generally acid, having a median $\mathrm{pH}$ of 3.1. Study of tailings solutions (BEG 1992) indicates that the acidity is due to the presence of hydrolyzing salts (aluminum sulfate and ferric iron sulfate). Also, the tailings solutions are generally oxidizing. This combination of conditions keeps many trace metals in solution by preventing adsorption and precipitation.

Evaporation of raffinates and drying of the tailings result in precipitation of relatively soluble sulfate salts within evaporation ponds and tailings piles. Dissolving these salts reconstitutes an acid solution because of the presence of aluminum and iron sulfate. Thus, dried tailings provide a source of acid leachates via percolation of rainfall and snowmelt through the tailings piles long after the original raffinate has drained from the tailings piles. Also, the concentrations of leachates vary considerably within a tailings pile, depending on the amount of dilution by precipitation or concentration by evaporation. Thus, large ranges in concentrations are observed in sampled tailings solutions both from different sites (Table 3 ) and from the same site. 
Table 3. Constituents in Tailings Solutions at Nine UMTRA Project Sites ${ }^{a}$

\begin{tabular}{|c|c|c|c|}
\hline Parameter & Frequency $^{\mathbf{b}}$ & Medianc & Range \\
\hline $\mathrm{pH}$ & $9 / 9$ & 3.1 & $0.8-7.1$ \\
\hline \multicolumn{4}{|c|}{ Constituents having UMTRA Project MCLs } \\
\hline $\begin{array}{l}\text { Nitrate } \\
\text { Uranium } \\
\text { Arsenic } \\
\text { Selenium } \\
\text { Molybdenum } \\
\text { Cadmium } \\
\text { Chromium } \\
\text { Lead } \\
\text { Silver } \\
\text { Barium } \\
\text { Mercury }\end{array}$ & $\begin{array}{l}7 / 7 \\
8 / 9 \\
9 / 9 \\
5 / 9 \\
9 / 9 \\
7 / 7 \\
7 / 7 \\
4 / 7 \\
4 / 7 \\
0 / 6 \\
6 / 6 \\
\end{array}$ & $\begin{array}{l}6.5 \\
2.9 \\
3.6 \\
2.05 \\
0.52 \\
0.32 \\
0.13 \\
0.03 \\
0.02 \\
<0.1 \\
0.0002 \\
\end{array}$ & $\begin{array}{c}0.2-6100 \\
0.3-675 \\
0.03-16 \\
<0.01-40 \\
0.14-23 \\
0.1-0.7 \\
0.03-4 \\
0.005-0.25 \\
<0.01-0.08 \\
- \\
0.0001-0.0003 \\
\end{array}$ \\
\hline $\begin{array}{l}\text { Radium - } 226 \\
\text { Radium-228 }\end{array}$ & $\begin{array}{l}3 / 3 \\
2 / 3\end{array}$ & $\begin{array}{r}148 \\
4.2\end{array}$ & $\begin{array}{l}12-280 \\
<1-6\end{array}$ \\
\hline \multicolumn{4}{|l|}{ Other metals } \\
\hline $\begin{array}{l}\text { Aluminum } \\
\text { Iron } \\
\text { Manganese } \\
\text { Zinc } \\
\text { Vanadium } \\
\text { Cobalt } \\
\text { Nickel } \\
\text { Beryllium } \\
\text { Copper } \\
\text { Thallium } \\
\text { Antimony } \\
\text { Tin } \\
\end{array}$ & $\begin{array}{l}7 / 7 \\
9 / 9 \\
8 / 8 \\
8 / 8 \\
9 / 9 \\
6 / 6 \\
7 / 7 \\
5 / 5 \\
6 / 6 \\
1 / 4 \\
5 / 6 \\
1 / 7 \\
\end{array}$ & $\begin{array}{r}860 \\
370 \\
61 \\
10 \\
3 \\
2.4 \\
1.8 \\
0.16 \\
0.13 \\
<0.05 \\
0.02 \\
<0.01 \\
\end{array}$ & $\begin{aligned} 0.4 & -6300 \\
0.1 & -2200 \\
1 & -360 \\
4.5 & -300 \\
0.3 & -250 \\
0.3 & -31 \\
0.2 & -25 \\
0.01 & -30 \\
0.03 & -4 \\
<0.03 & -0.4 \\
<0.003 & -0.1 \\
<0.01 & -0.25\end{aligned}$ \\
\hline \multicolumn{4}{|c|}{ Other constituents (nonmetals) } \\
\hline $\begin{array}{l}\text { Sulfate } \\
\text { Chloride } \\
\text { Sodium } \\
\text { Calcium } \\
\text { Magnesium } \\
\text { Silica } \\
\text { Potassium } \\
\text { Ammonium } \\
\text { Fluoride } \\
\text { Boron } \\
\text { Bromide } \\
\text { Phosphate }\end{array}$ & $\begin{array}{l}9 / 9 \\
9 / 9 \\
9 / 9 \\
9 / 9 \\
7 / 7 \\
7 / 7 \\
7 / 7 \\
6 / 6 \\
6 / 7 \\
7 / 7 \\
4 / 4 \\
3 / 5 \\
\end{array}$ & $\begin{array}{c}12700 \\
1100 \\
570 \\
560 \\
390 \\
99 \\
57 \\
58 \\
8.6 \\
1.3 \\
0.4 \\
0.03 \\
\end{array}$ & $\begin{aligned} 1600 & -66000 \\
27 & -6500 \\
94 & -16000 \\
420 & -670 \\
180 & -2600 \\
75 & -128 \\
6 & -220 \\
4 & -1020 \\
<0.1 & -58 \\
0.2 & -3 \\
0.3 & -15 \\
<0.1 & -27\end{aligned}$ \\
\hline \multicolumn{4}{|c|}{$\begin{array}{l}\text { Data are in milligrams per liter except for radium-226 and }-228 \text { (picocuries per liter) and pH (standard } \\
\text { units). } \\
\text { b Frequency indicates the number of sites where the constituent was detected followed by the number of } \\
\text { sites where the constituent was analyzed. } \\
\text { 'Median and range figures comprise maximum values observed in ground water at each site. }\end{array}$} \\
\hline
\end{tabular}




\section{DISTRIBUTION AND ATTENUATION OF CONTAMINANTS IN GROUND WATER}

Table 4 gives the occurrence of ground water contaminants (constituents in ground water which occur in excess of background levels or MCLs at 20 UMTRA Project sites. Three sites are not included in this analysis: Lowman, which has no processrelated contamination; Ambrosia Lake, which is complicated by extensive contamination associated with adjacent properties; and Maybell, for which data summaries were not readily available. The table provides an estimate of the upper bounds for contaminant concentrations in ground water. Maximum concentrations measured at each site provide the range of values for each contaminant, given that the value was above background levels. Values at or below background levels are not reflected in the range and median. Constituents are in the same order as in Table 3.

Process-related constituents that occur at elevated concentrations in ground water include sulfate, chloride, and sodium at nearly all UMTRA Project sites. Nitrate and ammonium occur at about half these sites. These two reagents were apparently not used at all sites. Major elements derived from ores, such as calcium, magnesium, potassium, and strontium also occur at elevated concentrations at most sites. Constituents that commonly occur in ground water above background levels include ore-enriched metals and metalloids (uranium, molybdenum, selenium, vanadium, and arsenic) and commonly occurring metals (iron, manganese, zinc, and nickel). Metals that rarely occur in ground waters at these sites are lead, silver, barium, mercury, aluminum, cobalt, beryllium, and thallium.

In general, the contaminants most prevalent in ground water are those which occur in the tailings solutions at high concentrations. Significant differences between the occurrence of constituents in the tailings solutions and in the ground water provide insight into contaminant attenuation. These differences are summarized in Table 5. This table is based on a comparison of concentrations in tailings solutions to concentrations in ground water at the nine UMTRA Project sites for which tailings solution data are available. At each site, for each metal, the maximum observed concentration in ground water was expressed as a percentage of the maximum concentration in the tailings solution. The percentages of attenuation given for each constituent are the median and range for all sites. In all cases, there was a large range of values for each constituent, from less than 1 percent to more than 100 percent of the tailings solution concentrations. This range probably reflects changes in contaminant source concentrations with time due to leaching of the tailings by precipitation over several years. The median value for each constituent, however, provides a semiquantitative measure of the degree of attenuation of contaminants near the tailings-subsoil interface. 
Table 4. Constituents in Ground Water Occurring Above Background Levels or MCLs at 20 UMTRA Project Sites ${ }^{\mathrm{a}}$

\begin{tabular}{|c|c|c|c|c|}
\hline Constituent & Frequencyb & Median $^{c}$ & Range & MCL \\
\hline \multicolumn{5}{|c|}{ Constituents having UMTRA Project MCLs } \\
\hline $\begin{array}{l}\text { Nitrate } \\
\text { Uranium } \\
\text { Arsenic } \\
\text { Selenium } \\
\text { Molybdenum } \\
\text { Cadmium } \\
\text { Chromium } \\
\text { Lead } \\
\text { Silver } \\
\text { Barium } \\
\text { Mercury }\end{array}$ & $\begin{array}{l}11 / 20 \\
20 / 20 \\
11 / 20 \\
13 / 20 \\
17 / 20 \\
9 / 20 \\
6 / 20 \\
2 / 20 \\
3 / 20 \\
0 / 20 \\
1 / 20\end{array}$ & $\begin{array}{l}1110 \\
\quad 1.2 \\
0.08 \\
0.3 \\
0.4 \\
0.06 \\
0.16 \\
0.06 \\
0.04 \\
- \\
- \\
\end{array}$ & $\begin{array}{c}45-5300 \\
0.014-70 \\
0.018-1.3 \\
0.02-21 \\
0.004-1.0 \\
0.1-0.7 \\
0.03-0.23 \\
0.04-0.07 \\
0.03-0.08 \\
- \\
0.009\end{array}$ & $\begin{array}{l}44 \\
0.044 \\
0.05 \\
0.01 \\
0.1 \\
0.01 \\
0.05 \\
0.05 \\
0.05 \\
2 \\
0.0002\end{array}$ \\
\hline $\begin{array}{l}\text { Radium - } 226 \\
\text { Radium-228 }\end{array}$ & $\begin{array}{l}7 / 20 \\
0 / 20\end{array}$ & $\begin{array}{r}17 \\
-\end{array}$ & $\begin{array}{c}1.3-654 \\
-\end{array}$ & $\begin{array}{l}5 \\
5\end{array}$ \\
\hline \multicolumn{5}{|l|}{ Other metals } \\
\hline $\begin{array}{l}\text { Aluminum } \\
\text { Iron } \\
\text { Manganese } \\
\text { Zinc } \\
\text { Vanadium } \\
\text { Cobalt } \\
\text { Nickel } \\
\text { Beryllium } \\
\text { Copper } \\
\text { Thallium } \\
\text { Antimony } \\
\text { Tin } \\
\end{array}$ & $\begin{array}{c}1 / 20 \\
15 / 20 \\
19 / 20 \\
15 / 20 \\
13 / 20 \\
3 / 20 \\
11 / 20 \\
1 / 20 \\
6 / 20 \\
2 / 20 \\
9 / 20 \\
5 / 20 \\
\end{array}$ & $\begin{array}{l}- \\
6.5 \\
7.5 \\
0.4 \\
0.4 \\
0.7 \\
0.3 \\
- \\
0.05 \\
0.2 \\
0.04 \\
0.09 \\
\end{array}$ & $\begin{array}{c}796 \\
0.1-460 \\
0.12-74 \\
0.03-7 \\
0.03-14 \\
0.4-1.2 \\
0.03-1.3 \\
0.6 \\
0.01-0.25 \\
0.06-0.4 \\
0.019-0.5 \\
0.02-0.2 \\
\end{array}$ & $\begin{array}{l}\text { N/A } \\
\text { N/A } \\
\text { N/A } \\
\text { N/A } \\
\text { N/A } \\
\text { N/A } \\
\text { N/A } \\
\text { N/A } \\
\text { N/A } \\
\text { N/A } \\
\text { N/A } \\
\text { N/A }\end{array}$ \\
\hline \multicolumn{5}{|c|}{ Other constituents (nonmetals) } \\
\hline $\begin{array}{l}\text { Sulfate } \\
\text { Chloride } \\
\text { Sodium } \\
\text { Calcium } \\
\text { Magnesium } \\
\text { Silica } \\
\text { Potassium } \\
\text { Ammonium } \\
\text { Fluoride } \\
\text { Boron } \\
\text { Bromide } \\
\text { Phosphate }\end{array}$ & $\begin{array}{c}19 / 20 \\
17 / 20 \\
18 / 20 \\
17 / 20 \\
16 / 20 \\
9 / 20 \\
16 / 20 \\
11 / 20 \\
7 / 20 \\
8 / 20 \\
5 / 20 \\
1 / 20\end{array}$ & $\begin{array}{r}4800 \\
970 \\
1430 \\
560 \\
450 \\
30 \\
50 \\
270 \\
2.7 \\
0.7 \\
0.5 \\
0.9\end{array}$ & $\begin{array}{c}210-15600 \\
40-6800 \\
60-5800 \\
100-2100 \\
26-2800 \\
12-200 \\
4-240 \\
12-1750 \\
1-12 \\
0.2-57 \\
0.3-19 \\
-\end{array}$ & $\begin{array}{l}\text { N/A } \\
\text { N/A } \\
\text { N/A } \\
\text { N/A } \\
\text { N/A } \\
\text { N/A } \\
\text { N/A } \\
\text { N/A } \\
\text { N/A } \\
\text { N/A } \\
\text { N/A } \\
\text { N/A }\end{array}$ \\
\hline \multicolumn{5}{|c|}{$\begin{array}{l}\text { aData in milligrams per liter except for radium- } 226 \text { and }-228 \text { (picocuries per liter). } \\
\text { b Frequency indicates the number of sites where the constituent was detected followed by the number of } \\
\text { sites where the constituent was analyzed. } \\
\text { "Median and range figures comprise maximum values observed in ground water at each site. } \\
\text { N/A = not analyzed. }\end{array}$} \\
\hline
\end{tabular}


Table 5. Attenuation of Constituents in Ground Water at Nine UMTRA Project Sites

\begin{tabular}{|c|c|c|c|}
\hline Parameter & Number of Comparisons & Median in Percent ${ }^{\mathrm{a}}$ & Range in Percent $t^{\mathrm{a}}$ \\
\hline \multicolumn{4}{|c|}{ Constituents having UMTRA Maximum Concentration Levels } \\
\hline $\begin{array}{l}\text { Nitrate } \\
\text { Uranium } \\
\text { Arsenic } \\
\text { Selenium } \\
\text { Molybdenum } \\
\text { Cadmium } \\
\text { Chromium } \\
\text { Lead } \\
\text { Silver } \\
\text { Barium } \\
\text { Mercury }\end{array}$ & $\begin{array}{l}7 \\
9 \\
9 \\
5 \\
8 \\
7 \\
7 \\
4 \\
4 \\
0 \\
0\end{array}$ & $\begin{array}{r}62 \\
16 \\
12 \\
15 \\
98 \\
12 \\
30 \\
40 \\
53 \\
- \\
-\end{array}$ & $\begin{array}{r}4->100 \\
0.3->100 \\
0.1->100 \\
1->100 \\
10->100 \\
0.6->100 \\
3->100 \\
20->100 \\
12->100 \\
- \\
-\end{array}$ \\
\hline $\begin{array}{l}\text { Radium - } 226 \\
\text { Radium-228 } \\
\end{array}$ & $\begin{array}{l}2 \\
0 \\
\end{array}$ & $\begin{array}{l}5 \\
- \\
\end{array}$ & $\begin{array}{c}<0.01-10 \\
-\end{array}$ \\
\hline \multicolumn{4}{|l|}{ Other metals } \\
\hline $\begin{array}{l}\text { Aluminum } \\
\text { Iron } \\
\text { Manganese } \\
\text { Zinc } \\
\text { Vanadium } \\
\text { Cobalt } \\
\text { Nickel } \\
\text { Beryllium } \\
\text { Copper } \\
\text { Thallium } \\
\text { Antimony } \\
\text { Tin } \\
\end{array}$ & $\begin{array}{l}7 \\
9 \\
8 \\
8 \\
9 \\
6 \\
7 \\
5 \\
8 \\
0 \\
0 \\
0 \\
\end{array}$ & $\begin{array}{c}2 \\
30 \\
74 \\
1.6 \\
6.8 \\
10 \\
16 \\
23 \\
0.4 \\
- \\
- \\
- \\
\end{array}$ & $\begin{aligned} 0.01->100 \\
0.1->100 \\
0.3->100 \\
0.01->96 \\
0.2->100 \\
0.3->100 \\
0.4->100 \\
0.03->100 \\
0.05->100 \\
- \\
- \\
-\end{aligned}$ \\
\hline \multicolumn{4}{|c|}{ Other constituents } \\
\hline $\begin{array}{l}\text { Sulfate } \\
\text { Chloride } \\
\text { Sodium } \\
\text { Calcium } \\
\text { Magnesium } \\
\text { Silica } \\
\text { Potassium } \\
\text { Ammonium } \\
\text { Fluoride } \\
\text { Boron } \\
\text { Bromide } \\
\text { Phosphate } \\
\end{array}$ & $\begin{array}{l}9 \\
9 \\
9 \\
7 \\
7 \\
7 \\
7 \\
6 \\
6 \\
7 \\
4 \\
0\end{array}$ & $\begin{array}{r}57 \\
88 \\
280 \\
120 \\
53 \\
43 \\
86 \\
62 \\
21 \\
100 \\
100 \\
-\end{array}$ & $\begin{array}{r}12->100 \\
17->100 \\
22->100 \\
98->100 \\
12->270 \\
17->150 \\
29->200 \\
4->100 \\
13->100 \\
<0.01->100 \\
38->100 \\
-\end{array}$ \\
\hline
\end{tabular}


One of the most important reactions resulting in attenuation of contaminant concentrations at the tailings-subsoil interface is the neutralization of the tailings seepage. The almost ubiquitous presence of carbonate minerals (generally calcite or calcium carbonate) in subsoil results in immediate neutralization of the tailings solutions beneath the tailings piles. Thus the $\mathrm{pH}$, which averages 3 in tailings solutions, generally increases to an average value of 7 in ground water near the tailings piles.

The increase in $\mathrm{pH}$ promotes precipitation of aluminum and iron (as hydroxides and sulfate salts) and the adsorption of several of the trace metals. Constituents that tend to be strongly attenuated (to less than 10 percent of their concentration in the tailings) are radium-226, aluminum, vanadium, and zinc. Constituents that are moderately attenuated (to 10 to 50 percent of tailings solution concentrations) are uranium, arsenic, selenium, cadmium, chromium, lead, iron, cobalt, nickel, beryllium, magnesium, silica, and fluoride. The neutralization, precipitation, and adsorption of several these constituents in subsoils have been investigated at several sites (DOE 1994, DOE 1985, Markos and Bush 1982). These studies have found that, in general, constituents precipitated and sorbed from percolating tailings solutions are concentrated in subsoil within about 1 meter of the base of tailings. This 1-meter general depth of soil is commonly removed during surface remediation because of the elevated levels of radium-226 and thorium-230.

Constituents that are more mobile across the tailings-subsoil interface include nitrate, molybdenum, manganese, sulfate, chloride, potassium, ammonium, boron, and bromide. These tend to occur in the most contaminated ground waters at about the same concentration as in tailings solutions. Of these, chloride, nitrate, and sulfate are generally good indicators of ground water contamination downgradient from tailings piles due to their high concentrations relative to background and chemically conservative nature. Two components, sodium and calcium, actually increase across the tailings-subsoil interface because of reactions involving cation exchange and calcium carbonate dissolution.

\section{CONTAMINANT ATTENUATION IN AQUIFERS}

Further attenuation of contaminants occurs within the aquifers at each UMTRA Project site. In general, finer-grained aquifers containing significant amounts of sand, silt, and clay are most effective at attenuating contaminants. By contrast, gravelbearing alluvial aquifers, which occur on floodplains at several of the sites, are least effective because of their low cation exchange and adsorption capacities resulting from lesser amounts of clay minerals and iron and manganese oxides. This effect is apparent in Table 6, where the sites are ranked according to the number of constituents that exceed MCLs. Typically, those sites which are immediately 
Table 6. Relation Between Aquifer Type and Numbers of Constituents Exceeding MCLs

\begin{tabular}{|c|c|c|c|c|}
\hline UMTRA Project Site & Aquifer Type & $\begin{array}{l}\text { Velocity } \\
\text { Category }^{\mathbf{a}}\end{array}$ & $\begin{array}{l}\text { Number of } \\
\text { Constituents } \\
\text { Exceeding } \\
\text { MCLs } \\
\end{array}$ & Constituents Abore MCLs ${ }^{\mathbf{b}}$ \\
\hline \multicolumn{5}{|c|}{ Sites with finer-grained aquifers } \\
\hline $\begin{array}{l}\text { Monument Valley, Arizona } \\
\text { Canonsburg, Pennsylvania } \\
\text { Lakeview, Oregon } \\
\text { Salt Lake City, Utah } \\
\text { Tuba City, Arizona }\end{array}$ & $\begin{array}{l}\text { Sand over sandstone } \\
\text { Sandy loam to silty clay loam, clay, fill } \\
\text { material } \\
\text { Silt, sand, sandy clay } \\
\text { Sand, silt, clay } \\
\text { Sandstone } \\
\end{array}$ & $\begin{array}{l}\text { High } \\
\text { High } \\
\text { Moderate } \\
\text { Low to moderate } \\
\text { Low } \\
\end{array}$ & $\begin{array}{l}1 \\
1 \\
2 \\
2 \\
3 \\
\end{array}$ & $\begin{array}{l}\mathrm{NO}_{3} \\
\mathrm{U} \\
\mathrm{Mo},(\mathrm{As}) \\
\mathrm{U}, \mathrm{Mo} \\
\mathrm{U}, \mathrm{Se}, \mathrm{NO}_{3} \\
\end{array}$ \\
\hline \multicolumn{5}{|c|}{ Sites with alluvial gravel aquifers } \\
\hline $\begin{array}{l}\text { Gunnison, Colorado } \\
\text { Riverton, Wyoming } \\
\text { Green River, Utah } \\
\text { Shiprock, New Mexico } \\
\text { Durango, Colorado } \\
\text { Grand Junction, Colorado } \\
\text { Naturita, Colorado } \\
\text { Lowman, Idaho } \\
\text { Mexican Hat, Utah } \\
\text { Rifle, Colorado (2 sites) } \\
\text { Slick Rock, Colorado } \\
\text { (2 sites) } \\
\end{array}$ & $\begin{array}{l}\text { Sand and gravel } \\
\text { Sand and gravel } \\
\text { Sand and gravel } \\
\text { Sand and gravel } \\
\text { Sand and gravel over sandstone } \\
\text { Sand and gravel } \\
\text { Sand and gravel } \\
\text { Sand and gravel and weathered } \\
\text { granodiorite } \\
\text { Fractured siltstone } \\
\text { Sand and gravel } \\
\text { Sand and gravel }\end{array}$ & $\begin{array}{l}\text { High } \\
\text { High } \\
\text { High } \\
\text { High } \\
\text { Moderate to high } \\
\text { Moderate to high } \\
\text { Low } \\
\text { Moderate } \\
\text { Low } \\
\text { High } \\
\text { High }\end{array}$ & $\begin{array}{l}1 \\
2 \\
3 \\
3 \\
4 \\
4 \\
4\end{array}$ & $\begin{array}{l}\mathrm{U} \\
\mathrm{U}, \mathrm{Mo} \\
\mathrm{U},(\mathrm{Se}), \mathrm{NO}_{3} \\
\mathrm{U}, \mathrm{Se}, \mathrm{NO}_{3} \\
\mathrm{U}, \mathrm{Se}, \mathrm{Mo}, \mathrm{Cd} \\
\mathrm{U}, \mathrm{Mo}, \mathrm{As}, \mathrm{Cd} \\
\text { (U), (Se), Mo, } \mathrm{Ra}-226 \\
\\
\mathrm{U}, \mathrm{Se}, \mathrm{Mo}, \mathrm{Cr}, \mathrm{NO}_{3} \\
\text { (U), Mo, } \mathrm{As}, \mathrm{Cd}, \mathrm{NO}_{3} \\
\text { (U), } \mathrm{Se},(\mathrm{Mo}), \mathrm{Cd}, \mathrm{NO}_{3}\end{array}$ \\
\hline \multicolumn{5}{|c|}{ Sites with natural uranium mineralization } \\
\hline $\begin{array}{l}\text { Belfield, North Dakota } \\
\text { Bowman, North Dakota } \\
\text { Spook, Wyoming } \\
\text { Falls City, Texas } \\
\text { Maybell, Colorado } \\
\end{array}$ & $\begin{array}{l}\text { Silty sandstone, claystone } \\
\text { Silty sandstone, claystone } \\
\text { Sandstone } \\
\text { Sandstone } \\
\text { Sandstone } \\
\end{array}$ & $\begin{array}{l}\text { Low } \\
\text { Low } \\
\text { High } \\
\text { High } \\
\text { Low } \\
\end{array}$ & $\begin{array}{l}1 \\
4 \\
5 \\
8 \\
7 \\
\end{array}$ & $\begin{array}{l}\text { (U) } \\
\text { (U), ( } \mathrm{Se}),(\mathrm{Mo}),\left(\mathrm{NO}_{3}\right) \\
\text { (U), (Se), (Cr), } \mathrm{NO}_{3}, \mathrm{Ra}-226 \\
\text { (U), (Se), Mo, } \mathrm{As}, \mathrm{Cd}, \mathrm{Hg}, \mathrm{NO}_{3},(\mathrm{Ra}-226) \\
\text { (U), (Se), Mo, As, Cd, NO}{ }_{3} \\
\end{array}$ \\
\hline
\end{tabular}


underlain by gravel aquifers have the greatest number of constituents that exceed MCLs in ground water, while those sites which are underlain by finer-grained sediments have the fewest number.

There are exceptions to this rule. The Gunnison, Colorado, UMTRA Project site is unusual in that the aquifer is gravel-bearing but has only one contaminant (uranium) in excess of MCLs. This may be because of the unusually thick nature of the gravel aquifer (over 30 meters thick), which appears to have promoted dispersion of contaminants. At most other sites having gravel aquifers, the gravels are relatively thin (about 9 meters or less) and overlie less permeable bedrock. Some UMTRA Project sites having fine-grained aquifers (Bowman, North Dakota, and Spook, Wyoming) are in areas of natural uranium mineralization. At these sites, it is not clear if elevated concentrations in ground waters occur from process-related contamination or ambient, natural conditions. Another exception is the Mexican Hat, Utah, UMTRA Project site, where fine-grained siltstones are fractured. Ground water flow within the fractures, as in gravels, provides little opportunity for adsorption and precipitation. A final exception is the Falls City, Texas, UMTRA Project site, where the fine-grained aquifer is virtually devoid of calcium carbonate. This is an unusual condition because less than 0.1 weight percent of calcium carbonate in the subsoil is sufficient to neutralize a pore volume of tailings solution. In the absence of neutralization, acid plumes at Falls City have migrated up to 600 meters from the tailings piles. The acid conditions inhibit adsorption and precipitation of most constituents. In addition, the site is located in a uranium-mineralized area.

Two specific examples serve to demonstrate the effect of neutralization on attenuation and the contrast between the attenuation capacity of finer-grained sediments and alluvial gravels. These examples are taken from ground water quality data collected at the Falls City, Texas, and Durango, Colorado, mill tailings sites.

The low acid neutralization potential of the Deweesville Sandstone at Falls City, Texas, has allowed acidic ground water to persist downgradient of the former tailings piles. A comparison of the water quality downgradient of the tailings with the tailings solutions (Table 7) demonstrates that certain constituents can be attenuated under acid conditions. These are arsenic, chromium, molybdenum, and vanadium-elements that occur as anionic species under the relatively oxidizing conditions found at the site. (Compare the first and second columns in Table 7.) All of these species are more strongly sorbed under acid conditions relative to neutral or alkaline conditions (Rai and Zachara 1984). By contrast, metals that occur as cationic species (cobalt, copper, nickel, and zinc) and that are more strongly adsorbed under neutral to alkaline conditions tend to be mobile in the acid ground waters. With neutralization (within the same sandstone unit; see the right-hand column in Table 7), the concentrations of the cationic metals also decrease to below detection. 
Table 7. Attenuation of Chemical Constituents in Acid and Neutralized Ground Water, Falls City, Texas, Uranium Processing Site ${ }^{\mathrm{a}, \mathrm{b}}$

\begin{tabular}{|c|c|c|c|c|}
\hline Constituent & $\begin{array}{l}\text { Average } \\
\text { Tailings } \\
\text { Solution }\end{array}$ & $\begin{array}{c}\text { Acidic } \\
\text { Down-gradient } \\
\text { Ground Water }\end{array}$ & $\begin{array}{c}\text { Neutralized } \\
\text { Down-gradient } \\
\text { Ground Water }\end{array}$ & Primary Cause of Attenuation \\
\hline $\begin{array}{l}\mathrm{pH} \\
\text { Chloride } \\
\text { Sulfate } \\
\text { Alkalinity } \\
\text { Calcium } \\
\text { Magnesium } \\
\text { Potassium } \\
\text { Sodium } \\
\text { Iron } \\
\text { Aluminum }\end{array}$ & $\begin{array}{r}3.3 \\
1401 \\
9114 \\
0 \\
493 \\
275 \\
188 \\
1060 \\
598 \\
715\end{array}$ & $\begin{array}{c}3.3 \\
7000 \\
1820 \\
0 \\
1750 \\
270 \\
76 \\
2070 \\
0.24 \\
109\end{array}$ & $\begin{array}{c}6.3 \\
1950 \\
1660 \\
1061 \\
1370 \\
120 \\
19 \\
730 \\
0.9 \\
0.4 \\
\end{array}$ & $\begin{array}{l}\text { Neutralization by carbonate minerals } \\
\text { None } \\
\text { Precipitation of sulfates } \\
\text { Buffered by carbonate minerals } \\
\text { Buffered by carbonate minerals } \\
\text { Cation exchange } \\
\text { Cation exchange } \\
\text { Cation exchange } \\
\text { Precipitation sulfates and oxides } \\
\text { Precipitation of sulfates and oxides }\end{array}$ \\
\hline $\begin{array}{l}\text { Arsenic } \\
\text { Chromium } \\
\text { Cobalt } \\
\text { Copper } \\
\text { Lead } \\
\text { Molybdenum } \\
\text { Nickel } \\
\text { Selenium } \\
\text { Uranium } \\
\text { Vanadium } \\
\text { Zinc } \\
\end{array}$ & $\begin{array}{c}2.2 \\
0.06 \\
0.8 \\
0.08 \\
<0.01 \\
1.25 \\
0.9 \\
<0.02 \\
8 \\
1.7 \\
4.3 \\
\end{array}$ & $\begin{array}{c}<0.01 \\
<0.01 \\
0.6 \\
0.03 \\
<0.005 \\
<0.01 \\
0.5 \\
0.1 \\
6 \\
0.1 \\
1.9 \\
\end{array}$ & $\begin{array}{l}\quad 0.05 \\
<0.05 \\
<0.03 \\
<0.01 \\
<0.01 \\
<0.01 \\
<0.04 \\
<0.005 \\
25 \\
<0.1 \\
<0.005 \\
\end{array}$ & $\begin{array}{l}\text { Adsorption } \\
\text { Adsorption } \\
\text { Adsorption } \\
\text { Adsorption } \\
\text { Adsorption } \\
\text { Adsorption } \\
\text { Adsorption } \\
\text { Adsorption } \\
\text { Adsorption } \\
\text { Adsorption } \\
\text { Adsorption } \\
\end{array}$ \\
\hline Radium-226 & 304 & 41 & 15 & Adsorption/coprecipitation \\
\hline
\end{tabular}


Chloride in the ground water, a conservative ion, tends to remain at or above levels found in the tailings solutions. The changes observed in the water quality are due to chemical reactions and not dilution. In fact, chloride concentrations suggest that shallow ground water at the Falls City UMTRA Project site is affected by evapotranspiration rather than dilution. Also, uranium concentrations appear to increase downgradient of the tailings. This may be from natural uranium associated with the widespread uranium mineralization at this site.

The contrast between the attenuation capacity of finer-grained sediments and alluvial gravels can be observed at Durango, Colorado UMTRA Project site. Here, ground water contaminated by raffinates has percolated down into alluvial gravels and into the underlying sandstone and shale bedrock. A comparison of the raffinate composition (identified in historic records) with contaminated ground water in basal alluvial gravel and the underlying bedrock is given in Table 8. Acid raffinates (with a $\mathrm{pH}$ of 0.8 ) seeping into the gravels were neutralized, so that the $\mathrm{pH}$ increased to about 7 , and diluted, as indicated by decreasing chloride concentrations. Nearly all constituents were attenuated by these processes; however, the concentrations of sulfate and hazardous metals remained at high levels within the gravels. By contrast, contaminants in the bedrock (between 6 and 15 meters below the gravel) are at much lower levels. Hazardous metals are generally below detection (with the exceptions of uranium, selenium, and zinc). Sodium and sulfate concentrations are also reduced, while chloride remains about the same. The decrease in sodium and sulfate is probably from cation exchange of sodium for calcium in clays, accompanied by the precipitation of calcium sulfate (gypsum). This illustrates the natural capacity of finer-grained sediments to attenuate hazardous constituents to near-background levels over a short distance. This is due to the greater presence, in fine-grained sediments, of materials having great capacity for cation exchange and adsorption, including clay minerals, iron oxides, and manganese oxides.

\section{BACKGROUND GROUND WATER QUALITY}

Background water quality is defined as the quality of water that would exist at the site if processing had not taken place. Table 9 summarizes the levels of constituents found in background ground waters at 17 UMTRA Project sites. Background water quality varies considerably from site to site and, in several cases, background ground water contains elevated concentrations of constituents that are also associated with the source term of contamination. Sulfate is a common example. At nearly half of the sites, sulfate exceeds the EPA secondary standard for sulfate in drinking water (250 milligrams per liter). However, in most cases, the level of sulfate is still within the range acceptable for livestock (3000 milligrams per liter; NAS 1972). Eight UMTRA Project sites are in areas on or adjacent to naturally occurring uranium deposits (Maybell, Falls City, Naturita, Rifle, Slick Rock, Belfield, Bowman, and 
Table 8. Attenuation of Chemical Constituents in Ground Water Beneath Raffinate Ponds at the Durango, Colorado, Uranium Processing Site $\mathbf{a}^{\mathbf{b}} \mathbf{b}$

\begin{tabular}{|c|c|c|c|c|c|}
\hline Constituent & $\begin{array}{c}\text { Source } \\
\text { Term } \\
\text { (raffinate) }\end{array}$ & $\begin{array}{l}\text { Shallow } \\
\text { Alluvial } \\
\text { Wells } \\
\left(\mathbf{n = 3 ) ^ { c }}\right.\end{array}$ & $\begin{array}{l}\text { Deeper } \\
\text { Bedrock } \\
\text { Wells } \\
(n=2)^{c}\end{array}$ & $\begin{array}{l}\text { Background } \\
\text { Bedrock } \\
\text { Well } \\
(n=1)^{c}\end{array}$ & Primary Cause of Attenuation \\
\hline $\begin{array}{l}\mathrm{pH} \\
\text { Chloride } \\
\text { Sulfate } \\
\text { Alkalinity }\end{array}$ & $\begin{array}{c}0.8 \\
6500 \\
66,000 \\
0\end{array}$ & $\begin{array}{r}7.2 \\
940 \\
12,000 \\
950\end{array}$ & $\begin{array}{r}7.5 \\
1100 \\
2000 \\
600\end{array}$ & $\begin{array}{r}8.0 \\
70 \\
700 \\
820\end{array}$ & $\begin{array}{l}\text { Neutralization by carbonate minerals } \\
\text { Dilution and dispersion } \\
\text { Precipitation of gypsum } \\
\text { Buffered by carbonate minerals }\end{array}$ \\
\hline $\begin{array}{l}\text { Calcium } \\
\text { Magnesium } \\
\text { Potassium } \\
\text { Sodium } \\
\text { Iron } \\
\end{array}$ & $\begin{array}{r}\text { N/A } \\
\text { N/A } \\
\text { N/A } \\
16,000 \\
370 \\
\end{array}$ & $\begin{array}{c}410 \\
450 \\
170 \\
4900 \\
0.1 \\
\end{array}$ & $\begin{array}{l}400 \\
290 \\
25 \\
900 \\
0.15\end{array}$ & $\begin{array}{r}115 \\
160 \\
7 \\
250 \\
0.02 \\
\end{array}$ & $\begin{array}{l}\text { Buffered by carbonate minerals } \\
\text { Buffered by carbonate minerals } \\
\text { Cation exchange } \\
\text { Cation exchange } \\
\text { Precipitation of iron hydroxides }\end{array}$ \\
\hline $\begin{array}{l}\text { Arsenic } \\
\text { Chromium } \\
\text { Cobalt } \\
\text { Copper } \\
\text { Lead } \\
\text { Molybdenum } \\
\text { Nickel } \\
\text { Selenium } \\
\text { Uranium } \\
\text { Vanadium } \\
\text { Zinc } \\
\end{array}$ & $\begin{array}{c}16 \\
\text { N/A } \\
\text { N/A } \\
23 \\
\text { N/A } \\
\text { N/A } \\
\text { N/A } \\
\text { N/A } \\
4.0 \\
250 \\
230\end{array}$ & $\begin{array}{c}0.02 \\
0.19 \\
0.10 \\
0.92 \\
0.02 \\
<0.05 \\
0.06 \\
2.7 \\
1.0 \\
0.15 \\
1.3 \\
\end{array}$ & $\begin{array}{r}<0.01 \\
<0.01 \\
<0.01 \\
<0.01 \\
<0.01 \\
<0.05 \\
<0.05 \\
0.01 \\
0.02 \\
<0.05 \\
0.08\end{array}$ & $\begin{array}{l}<0.005 \\
<0.005 \\
<0.005 \\
<0.005 \\
<0.005 \\
<0.01 \\
<0.01 \\
<0.03 \\
<0.005 \\
<0.005 \\
0.03 \\
\end{array}$ & $\begin{array}{l}\text { Adsorption } \\
\text { Adsorption } \\
\text { Adsorption } \\
\text { Adsorption } \\
\text { Adsorption } \\
\text { Adsorption } \\
\text { Adsorption } \\
\text { Adsorption } \\
\text { Adsorption } \\
\text { Adsorption } \\
\text { Adsorption }\end{array}$ \\
\hline Radium-226 & 148 & $<2.0$ & $<2.0$ & 0.6 & Adsorption/coprecipitation \\
\hline \multicolumn{6}{|c|}{$\begin{array}{l}\text { Data in milligrams per liter except for radium-226 (picocuries per liter). } \\
\text { b The symbol < indicates that concentration is below the detection limit (the number given). } \\
\text { cData listed are the average of constituent levels measured at wells sampled on the same date. The number of } \\
\text { wells included in the average is indicated by n. } \\
\text { N/A - not analyzed. }\end{array}$} \\
\hline
\end{tabular}


Table 9. Constituents in Background Ground Waters That Have Exceeded, at Least Once, Ground Water Standards ${ }^{a}$

\begin{tabular}{|c|c|c|c|c|}
\hline Constituent & Frequency ${ }^{\mathbf{b}}$ & Median ${ }^{c}$ & Range ${ }^{c}$ & Standard \\
\hline \multicolumn{5}{|c|}{ Constituents that have exceeded UMTRA Project MCLs ${ }^{\mathrm{d}}$} \\
\hline $\begin{array}{l}\text { Selenium } \\
\text { Uranium } \\
\text { Chromium } \\
\text { Molybdenum } \\
\text { Cadmium } \\
\text { Arsenic } \\
\text { Lead } \\
\end{array}$ & $\begin{array}{l}7 / 17 \\
5 / 17 \\
4 / 17 \\
2 / 17 \\
2 / 17 \\
2 / 17 \\
1 / 17 \\
\end{array}$ & $\begin{array}{l}0.05 \\
0.06 \\
0.08 \\
0.20 \\
0.02 \\
0.09 \\
0.14 \\
\end{array}$ & $\begin{array}{c}0.012-1.1 \\
0.05-2.9 \\
0.06-0.09 \\
0.2-0.2 \\
0.02-0.03 \\
0.06-0.11 \\
- \\
\end{array}$ & $\begin{array}{l}0.01 \\
0.044 \\
0.05 \\
0.1 \\
0.01 \\
0.05 \\
0.05 \\
\end{array}$ \\
\hline \multicolumn{5}{|c|}{ Constituents that have exceeded EPA primary drinking water standards ${ }^{\mathrm{e}}$} \\
\hline Antimony & $8 / 17$ & 0.012 & $0.007-0.09$ & 0.006 \\
\hline \multicolumn{5}{|c|}{ Constituents that have exceeded EPA secondary drinking water standards $\mathrm{f}$} \\
\hline $\begin{array}{l}\text { Manganese } \\
\text { Sulfate } \\
\text { Iron } \\
\text { Chloride } \\
\text { Fluoride } \\
\end{array}$ & $\begin{array}{l}12 / 17 \\
11 / 17 \\
9 / 17 \\
2 / 17 \\
1 / 17 \\
\end{array}$ & $\begin{array}{c}0.8 \\
1040 \\
2.4 \\
680 \\
4.7 \\
\end{array}$ & $\begin{array}{c}0.15-4.2 \\
390-3300 \\
0.08-12 \\
260-1090 \\
- \\
\end{array}$ & $\begin{array}{c}0.05 \\
250 \\
0.05 \\
250 \\
4 \\
\end{array}$ \\
\hline \multicolumn{5}{|c|}{ 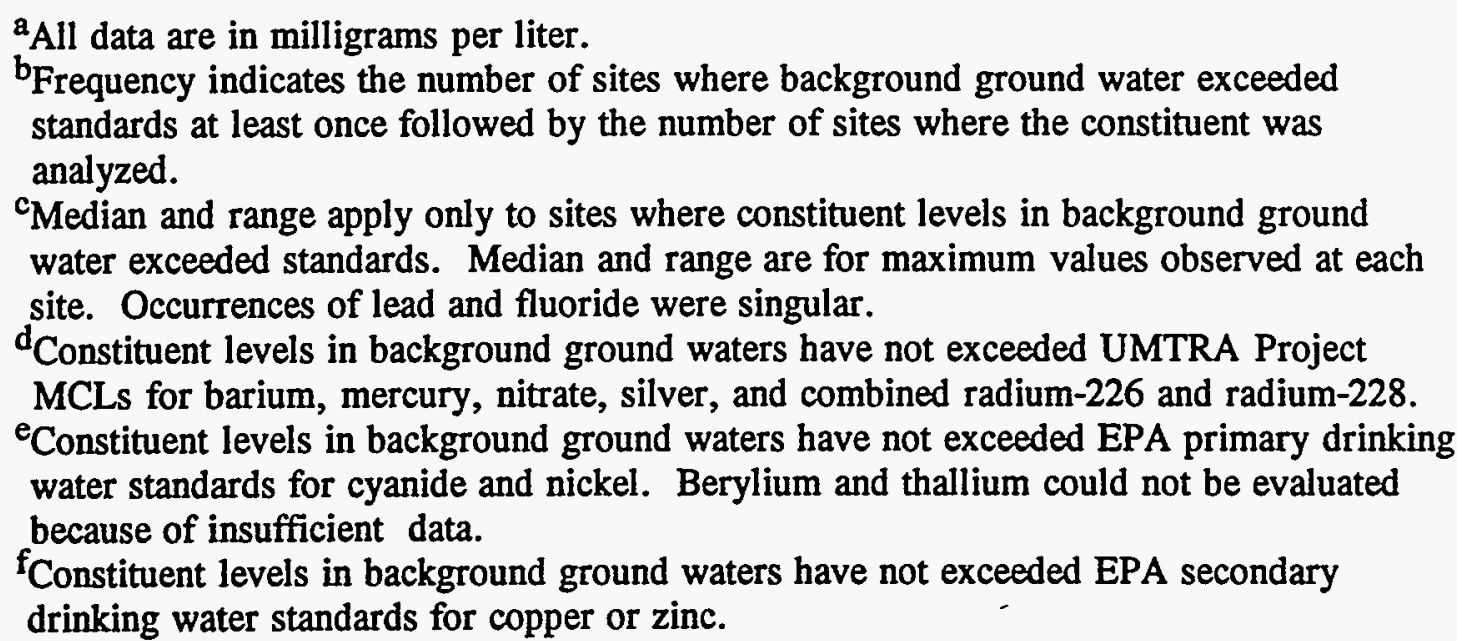 } \\
\hline
\end{tabular}


Spook). Ground water at these sites typically contains uranium, selenium, chromium, and molybdenum. Natural ground water upgradient of the Lakeview, Oregon, UMTRA Project site is geothermal and contains naturally high levels of arsenic and molybdenum.

\section{UMTRA PROJECT GROUND WATER REMEDIAL ACTION SELECTION}

The stabilization of the surface contamination at the 24 UMTRA Project sites is almost evenly divided between stabilization on the site and disposal off the site. Most sites that have tailings relocated away from the site are either in urban settings or in river floodplains. Tailing stabilization was done to protect human health and the environment by reducing radon emanations and isolating the tailings from the environment. Stabilization of the mill tailings effectively removes the primary source of ground water contamination and is an important first step in ground water remediation.

The purpose of the UMTRA Ground Water Project is to protect human health and the environment by meeting EPA ground water standards in areas where ground water has been contaminated with constituents from former processing sites. The EPA standards establish numerical concentration limits based on MCLs or background concentrations for those contaminants expected to be associated with the uranium milling processes. Alternate concentration limits (ACL) may be established for contaminants without an established MCL or where a contaminant at a concentration above MCLs or background demonstrates no significant risk to human health or the environment. Supplemental standards may be established if such standards come as close to meeting the otherwise applicable standards as is reasonably achievable under the circumstances and protect human health and the environment. Supplemental standards are warranted under one of the following conditions: ground water at the site is of limited use in the absence of contamination from residual radioactive materials; complete restoration would cause more environmental harm than it would prevent; or complete restoration is technically impracticable from an engineering perspective.

Each UMTRA Project site's compliance strategy is directed toward satisfying the applicable EPA standards. The principal compliance strategies are: no further action through a demonstration of regulatory compliance, passive or natural flushing (allowing the natural flow of ground water to cleanse the aquifer), and active (engineered) remedial actions.

The strategy of no further action applies to UMTRA Project sites having no contamination and those sites where conditions warrant applying supplemental standards or ACLs. The strategy of passive compliance is targeted at sites where it 
can be demonstrated that natural flushing of the aquifer will reduce contaminant concentrations to MCLs, ACLs, or background concentrations within 100 years, provided that human health and the environment can be protected during this period.

Active compliance strategies include engineered methods, such as gradient manipulation, contaminant isolation, ground water extraction, ground water treatment, in situ ground water treatment, and innovative technologies. Active compliance strategies would be used where passive compliance would not meet EPA standards, not adequately protect human health or the environment, or not be accepted by the public.

Table 10 provides the targeted ground water remedial action strategy proposed for each UMTRA Project site. No further action was selected as the targeted remedial action at 12 of the 24 UMTRA Project sites. In general, sites with high attenuation, usually with fine-grained aquifers, are good candidates for regulatory compliance. UMTRA Project sites such as Canonsburg, Lakeview, and Salt Lake City are good examples. In general, sites with natural uranium mineralization are also good candidates for regulatory compliance because of preexisting high levels of natural mineralization. For example, UMTRA Project sites such as Falls City, Spook, Maybell, Ambrosia Lake, Belfield, and Bowman are located in areas of poor background ground water quality. One UMTRA Project site (Lowman, Idaho) was selected for a strategy of no further action because no ground water contamination related to mill processing activities was identified.

Natural flushing was selected as the targeted remedial action at 10 of the UMTRA Project sites. In general, sites where natural flushing is targeted have some attenuation potential but have moderate to high ground water velocities, which have the capacity to decrease contaminant concentrations by the process of dispersion.

Active remediation was selected at two UMTRA Project sites (Monument Valley and Tuba City). Both sites are characterized as having finer-grained aquifers and greater attenuation potential, which have contributed to a low number of constituents exceeding MCLs. However, high levels of nitrate require an active approach to remedial action.

\section{SUMMARY}

Former uranium processing activities at most of the designated 24 UMTRA Project inactive mill sites resulted in the contamination of ground water beneath and, in some cases, downgradient of the sites. This paper has described the radiological and nonradiological constituents found in ground water at a typical U.S. uranium milling facility. Geochemical characterization at these sites is important in defining ground 
Table 10. Targeted Ground Water Remedial Strategies at the UMTRA Project Sites

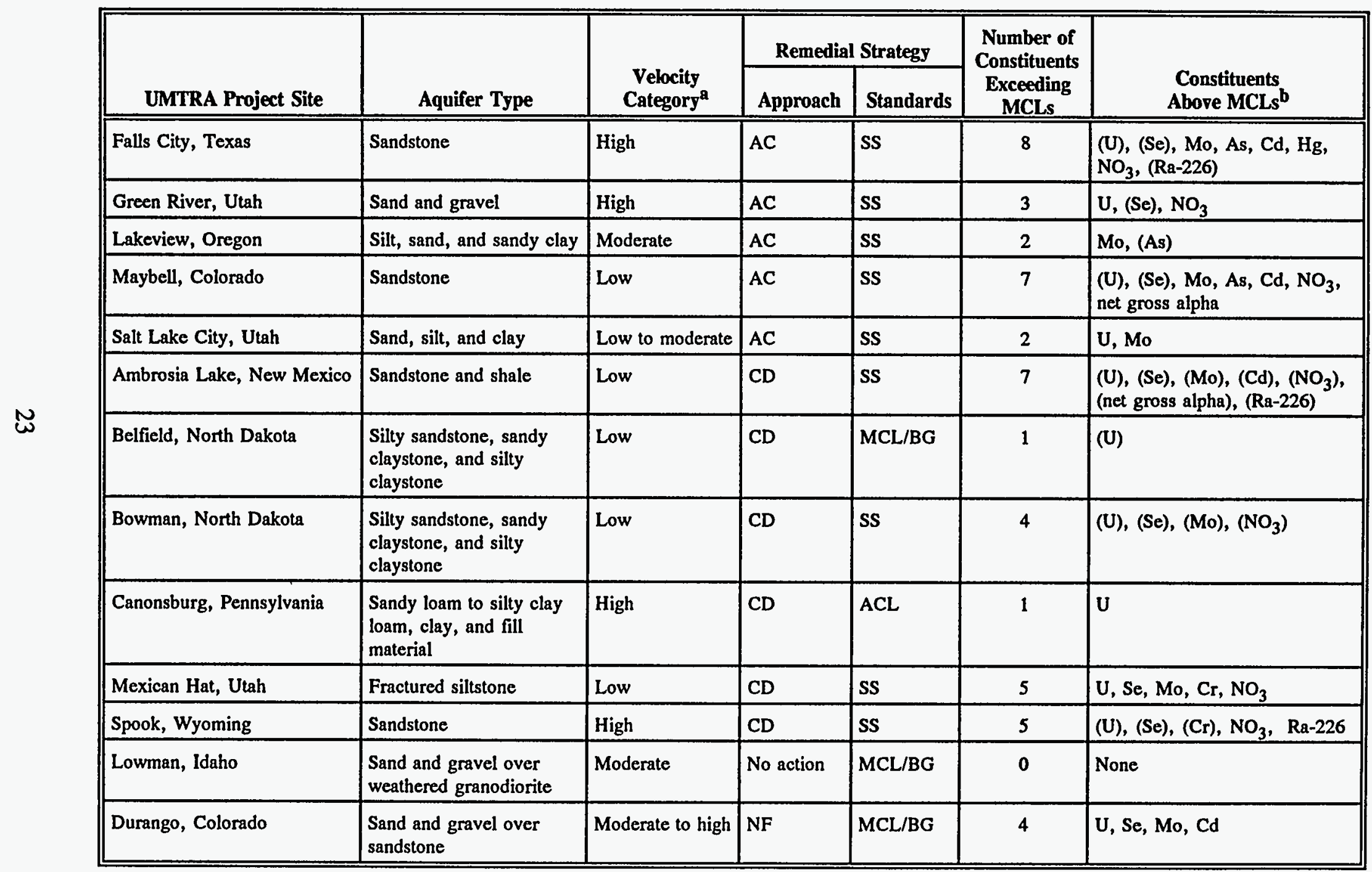


Table 10. Proposed Ground Water Remedial Strategies at the UMTRA Sites (Concluded)

\begin{tabular}{|c|c|c|c|c|c|c|}
\hline \multirow[b]{2}{*}{ UMTRA Project Site } & \multirow[b]{2}{*}{ Aquifer Type } & \multirow{2}{*}{$\begin{array}{c}\text { Velocity } \\
\text { Category }^{\mathrm{a}} \\
\end{array}$} & \multicolumn{2}{|c|}{ Remedial Strategy } & \multirow{2}{*}{$\begin{array}{c}\text { Number of } \\
\text { Constituents } \\
\text { Exceeding } \\
\text { MCLs } \\
\end{array}$} & \multirow[b]{2}{*}{$\begin{array}{l}\text { Constituents } \\
\text { Above MCLs }^{\mathrm{b}} \\
\end{array}$} \\
\hline & & & Approach & Standards & & \\
\hline Grand Junction, Colorado & Sand and gravel & Moderate to high & NF & $\mathrm{MCL} / \mathrm{BG}$ & 4 & $\mathrm{U}, \mathrm{Mo}, \mathrm{As}, \mathrm{Cd}$ \\
\hline Gunnison, Colorado & Sand and gravel & High & NF & $\mathrm{MCL} / \mathrm{BG}$ & 1 & $\mathbf{U}$ \\
\hline Naturita, Colorado & Sand and gravel & Low & NF & MCL/BG & 4 & (U), (Se), Mo, Ra-226 \\
\hline Riffe, Colorado ( 2 sites) & Sand and gravel & High & NF & $\mathrm{MCL} / \mathrm{BG}$ & 5 & (U), $\mathrm{Mo}, \mathrm{As}, \mathrm{Cd}, \mathrm{NO}_{3}$ \\
\hline Riverton, Wyoming & Sand and gravel & High & NF & $\mathrm{MCL} / \mathrm{BG}$ & 2 & U, Mo \\
\hline Shiprock, New Mexico & Sand and gravel & High & NF & MCL/BG & 3 & $\mathrm{U}, \mathrm{Se}, \mathrm{NO}_{3}$ \\
\hline Slick Rock, Colorado (2 sites) & Sand and gravel & High & NF & $\mathrm{MCL} / \mathrm{BG}$ & 5 & $(\mathrm{U}), \mathrm{Se},(\mathrm{Mo}), \mathrm{Cd}, \mathrm{NO}_{3}$ \\
\hline Monument Valley, Arizona & Sand over sandstone & High & active & MCL/BG & 1 & $\mathrm{NO}_{3}$ \\
\hline Tuba City, Arizona & Sandstone & Low & active & $\mathrm{MCL} / \mathrm{BG}$ & 3 & $\mathrm{U}, \mathrm{Se}, \mathrm{NO}_{3}$ \\
\hline \multicolumn{7}{|c|}{$\begin{array}{l}\text { a Ground water velocity categories: low }<15 \text { meters per year, moderate } 15 \text { to } 30 \text { meters per year, high }>30 \text { meters per year. } \\
\text { bParentheses surrounding a ground water constituent indicate ambient background contamination. }\end{array}$} \\
\hline
\end{tabular}


water contaminants related to uranium processing activities and in determining contaminant interactions with the aquifer matrix. Geochemical characterization efforts are essential to developing ground water compliance strategies to meet long-term management requirements identified in the Uranium Mill Tailings Radiation Control Act.

\section{REFERENCES}

BEG (Bureau of Economic Geology) 1992. Hydrogeology and Hydrochemistry of Falls City Uranium Mine Tailings Remedial Action Project, Karnes County, Texas, The University of Texas at Austin, Austin, Texas.

DOE (U.S. Department of Energy) 1985. Processing Site Characterization Report of the Uranium Mill Tailings at Lakeview, Oregon, UMTRA-DOE/AL050106.0000 , draft, prepared by the U.S. Department of Energy, UMTRA Project Office, Albuquerque Operations Office, Albuquerque, New Mexico.

DOE (U.S. Department of Energy) 1994. Gunnison, Colorado, Subpile Report, UMTRA-DOE/AL/62350-110, March 1994, prepared by the U.S. Department of Energy, UMTRA Project Office, Albuquerque Operations Office, Albuquerque, New Mexico.

Krauskoff, Konrad B. 1967. Introduction to Geochemistry, Mcgraw-Hill Book Company, New York, New York.

Markos, G., and K. J. Bush 1982. Geochemical Investigation of UMTRAP Designated Site at Salt Lake City, Utah, GECR \#R-826, Contract \# DEAC04-82AL18797, Document DOE/UMT/0235, prepared by GECR, Inc., Rapid City, South Dakota, prepared for the U.S. Department of Energy, UMTRA Project Office, Albuquerque Operations Office, Albuquerque, New Mexico.

Merritt, R. C. 1971. The Extractive Metallurgy of Uranium, Colorado School of Mines Research Institute, Golden, Colorado.

NAS (National Academy of Sciences) 1973. Water Quality Criteria 1972, A Report of the Committee on Water Quality Criteria, prepared for the U.S. Environmental Protection Agency, Ecological Research Series, PB-236 199. 
Rai, D. and J. M. Zachara 1984. Chemical Attenuation Rates, Coefficients, and Constants in Leachate Migration, Volume 1: A Critical Review, prepared by Battelle, Pacific Northwest Laboratories for Electric Power Research Institute, EA-3356, Volume 1, Research Project 2198-1.

Tame et al. (K. E. Tame, E. G. Valdez, and J. B. Rosenbaum) 1961. Disposal of Liquid Waste in the Durango-type Uranium Milling Flowsheet, U.S. Dept. of the Interior, Bureau of Mines.

Tsivoglou et al. (E. C. Tsivoglou, S. D. Shearer, J. D. Jones, C. E. Sponagle, H. R. Pahren, J. B. Anderson, and D. A. Clark) 1960 . Survey of Interstate Pollution of the Animas River (Colorado-New Mexico); II 1959 Surveys, U. S. Department of Health, Education, and Welfare, Public Health Services, Bureau of State Services, Division of Water Supply and Pollution Control. 